\title{
Byerne i Slesvig ca. 1700-1830 - en variant af dansk købstadshistorie
}

\author{
af LARS N. HENNINGSEN
}

Købstæderne i Slesvig gør i perioden 1700-1830 Kongerigets købstæder rangen stridig som de førende søfarts- og handelsbyer. Omkring 1800 var Flensborg en stærk konkurrent til Kobenhavn. Forfatteren undersøger baggrunden for de slesvigske byers bemærkelsesværdige udvikling - og gør bl.a. rede for forskellen mellem de østlige og vestlige købstæders vilkår.

1700-årenes danske monarki havde en geografisk afgrænsning, som var anderledes end vore dages Kongerige Danmark. I dag danner landsdelen Sønderjylland eller Nordslesvig grænseområde til Tyskland. Grænsen går i vest syd om byen Tønder og i øst nord om byen Flensborg. Denne grænse blev trukket efter en folkeafstemning i 1920 midt gennem det gamle hertugdømme Slesvig.

Frem til 1864 strakte den danske konges område sig helt til floden Elben. Det egentlige Kongerige Danmark havde grænse mod syd ved Kongeåen. Grænsen gik syd for byerne Kolding og Ribe. Syd derfor lå de to hertugdømmer Slesvig og Holsten. Længst mod syd, mellem Ejderen og Elben, lå hertugdømmet Holsten, nord derfor hertugdømmet Slesvig eller Sønderjylland. Begge hertugdømmer blev forvaltet af den danske konge, men statsretsligt havde de en særstilling. Slesvig var et len af Danmark, Holsten var et len af det tysk-romerske kejserrige. Lovgivning og forvaltning $\mathrm{i}$ de to hertugdømmer var på mange måder anderledes end i Kongeriget. Centralforvaltning og lovgivning udgik fra København, men lokalt i hertugdømmerne var der melleminstanser mellem byerne og centralforvaltningen. Vigtigst var kongens »statholder « og "Overretten ", begge med sæde i Slesvig by. Kongeåen var toldgrænse. Produkter med oprindelse $\mathbf{i}$ hertugdømmerne slap dog med en lav mellemrigstold, når de blev fort til Kongeriget. $^{1}$

På en række områder var de formelle rammer for bylivet anderledes $\mathrm{i}$ hertugdømmerne end $\mathrm{i}$ Kongeriget. Byerne var ikke underlagt tilsyn af den stedlige amtmand, men sorterede direkte under stathol- 


\section{,}

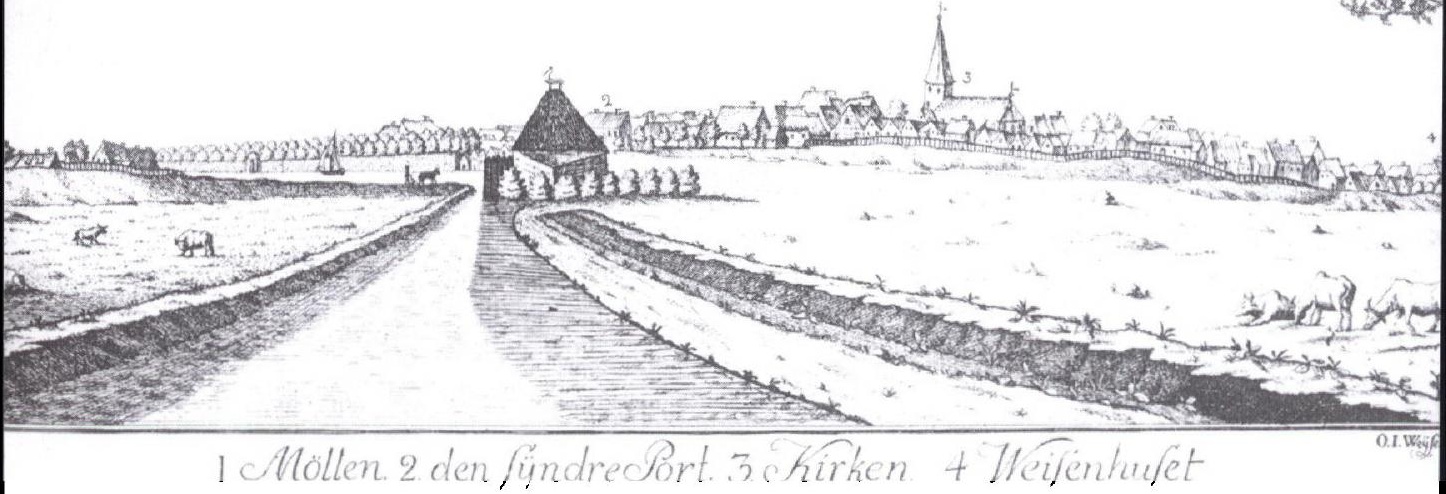

Erik Pontoppidans store topografiske zærk Den danske Atlas, som udkom $i 7$ bind mellem 1763 og 1781, er en god kilde til kobstædernes udseende $i$ 1700-tallet. Hoer by er reprasenteret med en grundplan og et prospekt. Hvis man sammenligner disse illustrationer, fär man et indtryk af det karakteristiske for datidens byer og af forskelle og ligheder byerne imellem. Tonder fremtræder som en typisk vestkystby. Byen gemmer sig bag det frugtbare opland med de mange grassende stude. Kun en ganske

deren og centralmyndighederne i København. Forbrugsafgiften konsumtion gjaldt ikke syd for Kongeåen. Et vist mål af lokal, kommunal selvforvaltning fik lov at leve længere i byerne syd for Kongeåen end i Kongeriget. Centraladministrationens ønske om tilsyn, kontrol og udjævning af lokale forskelle gjorde sig i mindre grad gældende $\mathrm{i}$ hertugdømmerne end i Kongeriget, men var dog også her i fremvækst gennem $1700 a ̊ r e n e .{ }^{2}$

I det følgende vil vi begrænse synsfeltet til hertugdømmet Slesvig. I næsten to århundreder frem til 1721 var Slesvig delt mellem den danske konge og den gottorpske hertug. Det medførte forskelle mellem kongens byer og hertugens byer hvad angår lovgivning og handelsforbindelser. I 1721 blev hele Slesvig imidlertid samlet under kongen. Fra nu af var alle byerne i større eller mindre grad afhængige af 

og vest. Eneste hindring var byernes besejlings- og havneforhold. Store skibe kunne ikke løbe helt ind i havnene. Alligevel lykkedes det vestkystbyerne at bevare en betydelig transithandel med varer fra syd og vest til midtlandet og til østkysten af Slesvig.

Østkystens byer var bedre stillet i forhold til transportvejene. Kun Haderslev i nord og Slesvig i syd havde ikke gode havneforhold. Alle de øvrige, Ekernførde, Flensborg, Sønderborg og Aabenraa lå med gode naturhavne ved bugter eller fjorde, der strakte sig ind $i$ landet. De var en ideel base for sejlads på Østersøen med dens bugnende adgang til vigtige råstoffer, som var efterspurgte i Vest- og Sydeuropa. Rundt om og bag byerne lå et frugtbart monæneland præget af bondegårde og godser - med betydeligt opdræt af kvæg, mejeridrift og kornavl. Landbrugerne i oplandet leverede varer til bykøbmændenes eksport og aftog varer importeret til byerne udefra. Østkystbyernes naturlige forbindelser gik mod øst og nord.

Slesvigs midtland var $\mathbf{i}$ forhold til de ekstremt rige marskområder mod vest og til de frugtbare landbrugsområder mod øst præget af magre jorder. Her opstod ikke egentlige byer. Midtlandet var snarere kystbyernes naturlige bagland, både som leverandør af landbrugsvarer og husflidsprodukter og aftager af varer fra byerne. ${ }^{3}$

Alt $i$ alt dannede Slesvig takket være sin beliggenhed et godt udgangspunkt for byudvikling. Slesvig fik en meget fremtrædende plads i det danske bylandskab. Målt efter indbyggertal lå de slesvigske byer blandt de største danske købstæder. ${ }^{4}$

Indbyggertal

\begin{tabular}{lcc}
\hline & 1769 & $1801 / 03$ \\
\hline Kongeriget Danmark & 815.000 & 926.000 \\
Slesvig & 243.605 & 276.000 \\
\hline
\end{tabular}


Storste byer $i$ Kongeriget Danmark (DK) og Slesvig (S)

\begin{tabular}{lcr}
\hline & & $1801 / 03$ \\
\hline København & (DK) & 100.975 \\
Flensborg & (S) & 10.666 \\
Slesvig & (S) & 7.823 \\
Odense & (DK) & 5.782 \\
Aalborg & (DK) & 5.579 \\
Helsingør & (DK) & 5.282 \\
Randers & (DK) & 4.562 \\
Aarhus & (DK) & 4.102 \\
Husum & (S) & 3.658 \\
Fredericia & (DK) & 3.474 \\
Ekernførde & (S) & 2.921 \\
Aabenraa & (S) & 2.834 \\
Sønderborg & (S) & 2.761 \\
Haderslev & (S) & 2.685 \\
Tønder & (S) & 2.579 \\
\hline
\end{tabular}

Målt efter skibstonnage lå de slesvigske byer i første række:

Skibstonnage ${ }^{5}$

\begin{tabular}{lrc}
\hline & $1782 / 83$ & $1800 / 1806$ \\
\hline København & $28.770 \mathrm{kl}$. & $25.791 \mathrm{kl}$. \\
Kongeriget i øvrigt & $8.133 \mathrm{kl}$. & $12.325 \mathrm{kl}$. \\
Hertugdømmet Slesvig & $14.000 \mathrm{kl}$. & $27.707 \mathrm{kl}$. \\
heraf Flensborg by & $7.047 \mathrm{kl}$. & $15.456 \mathrm{kl}$. \\
$\quad$ Sønderborg & $1.784 \mathrm{kl}$. & $2.497 \mathrm{kl}$. \\
Aabenraa & $2.148 \mathrm{kl}$. & $2.106 \mathrm{kl}$. \\
\hline
\end{tabular}

Anm.: En kommercelæst (kl.) er to nettoregistertons a $2,83 \mathrm{~m}^{3}$.

\section{Købstæder mellem søfart og landhandel}

Østkystens havnebyer var i fremgang i 1700-årene. De levede bl. a. af at importere varer fra Østersøområdet - bygningstømmer, jern, kalk, tjære, hør, korn osv. og forsynede oplandet helt ud på den træfattige vestkyst. 
Det bedste opland havde »den temmelig store, rige og skønne handelsby " Flensborg. "For at sælge og købe hvad de har brug for drager landboerne hellere langvejs fra til Flensborg end til andre slesvigske byer «, hedder det i 1799. Det meste af Nordslesvig og store dele af Sydslesvig, ja Ditmarsken var både kunde og leverandør til Flensborg, og Flensborg-købmændene var grossister for kollegerne i Nordslesvig. Flensborgs store handelshuse leverede hør, salt, tømmer, jern, kolonialvarer og vin til det vidtstrakte opland. Handlende fra Flensborg var ofte i flertal på markederne $\mathrm{i}$ nabobyerne mod nord. Ikke uden grund klagede alle nabobyerne til stadighed over den overmægtige konkurrence. Næsten halvdelen af den samlede import fra udlandet til Slesvig gik i 1765 over Flensborg - således 4/5 af importen fra Frankrig, 3/4 fra Kurland, Livland og Rusland og knap $60 \%$ af de svenske varer. ${ }^{6}$

På vestkysten var byernes søhandel i tilbagegang. Tilsandende havne voldte problemer i Husum, Frederiksstad og Tønning. I Tønder havde digebyggeriet forlængst afbrudt den direkte forbindelse med havet, og varerne måtte i stedet afskibes fra Højer og Rudbøl. Det hindrede dog ikke en udstrakt handel på Hamborg, Altona og Holland, både ad landevejen og søvejen. De importerede kolonialvarer og især tobak blev sendt videre helt ud på østkysten. Eksporthandel med korn, smør og ost og med stude og heste fra Slesvig og Jylland gav god næring i de tre store vestkystbyer. Over halvdelen af den samlede udførsel til udlandet fra Slesvig gik over Tonning, Husum og Frederiksstad, især til Hamborg, Altona og Holland. Mest stille var der i Frederiksstad. Denne by havde ikke som de øvrige rod i middelalderen. Den var grundlagt i 1621 af hertug Friedrich III på Gottorp og befolket af indkaldte trosflygtninge fra Nederlandene. Udstyret med trosfrihed og erhvervsøkonomiske privilegier var det planen, at de skulle opbygge handel på Frankrig, Algier, Spanien, Portugal og Persien. En sådan overregional betydning fik byen dog aldrig, og det lykkedes ikke byen at vinde et større opland i konkurrence med naboerne.

Byernes vareomsætning var utænkelig uden søfarten. Aabenraa, Sønderborg, Flensborg og Ekernførde rådede alene over 3/4 af den slesvigske tonnage. En stadig flåde af skibe sejlede fra og til Danmark med levnedsmidler. Især Københavns umættelige behov lagde beslag på mange ladninger korn, flæsk, brænde og mursten, eller tekstiler fra den lokale husflid. Byernes større skibe sejlede på Østersøen, Nor- 
ge eller England og hentede basisvarerne til den hjemlige handel. Især Aabenraa-skibene var længe specialiseret i trekantsfart mellem Sverige, Norge og England - indtil den svenske beskyttelseslovgivning efter 1724 lagde tømmereksporten fra Sverige over på svenske skibe. Fra hovedbyen Flensborg gik mange af de hjemlige skibe helt til Frankrig og hjembragte vin, blommer, sukker eller salt til omsætning hjemme eller i Østersøregionen.

Skibene fra Slesvig og Holsten begrænsede sig dog ikke til at transportere varer for rederne eller hjemlige købmænd, og denne fart kan ikke forklare, at skibsflåden blev så stor, sammenlignet med Kongeriget. Karakteristisk er derimod, at de store søfartsbyer også drev fragtfart uden snæver forbindelse til hjembyens egen vareomsætning. Nødvendigheden tvang dertil. I 1726 fik København importmonopol på salt, tobak, vin og udenlandsk spiritus. I 1742 lagde den såkaldte "kommerceforordning « høj told på al import, som ikke skete direkte fra produktionslandet og på danske skibe. Dermed var der lagt alvorlige hindringer for de slesvigske byers varehandel på Danmark. Især Flensborg folte sig ramt, men også andre byer klagede gang på gang over "forbudet mod handel med Danmark «. Det betød, at søfarten ikke kunne baseres på udførsel af hjemlige produkter eller vareomsætning på Kongeriget.

Skibene søgte i stedet over i fragtfart for udenlandsk eller dansk regning, med så stort held, at hertugdømmerne i 1700-årene blev hjemsted for en søfart helt ukendt i Kongerigets provinsbyer.

Slesvigske skibe blev allerede i 1720'erne flittigt brugt af redere i København, til fragtfart på Nordatlanten og mellem Sverige, England, Holland, Frankrig og hovedstaden. I 1745 modtog hovedstaden 36 af 128 skibsladninger fra Norge på skibe indregistreret i Aabenraa og Sønderborg, og fra udlandet ankom 120 ladninger med slesvigske skibe. Danske provinsskibe tegnede sig for kun 36 ladninger. Det gav fremgang - også i de ellers lidt stille år frem til 1740. I Ekernførde voksede tonnagen fra 277 læster i 1720 til 597 i 1740 . Aabenraa stormede frem i disse år. I 1721 lå indbyggertallet på ca. 1.250, og tonnagen på noget under 1.600 kommercelæster. Frem til o. 1750 voksede byen til lidt over 3.000 indbyggere og tonnagen til ca. 4.300 læster byen overfløj den ellers vigtigste by Flensborg. Baggrunden var en omfattende søfart på Sverige, Island og England. ${ }^{7}$

Men det var kun starten. Endnu i 1730'erne havde frygten for at falde i kløerne på kapere fra Nordafrika holdt de fleste skibe borte 


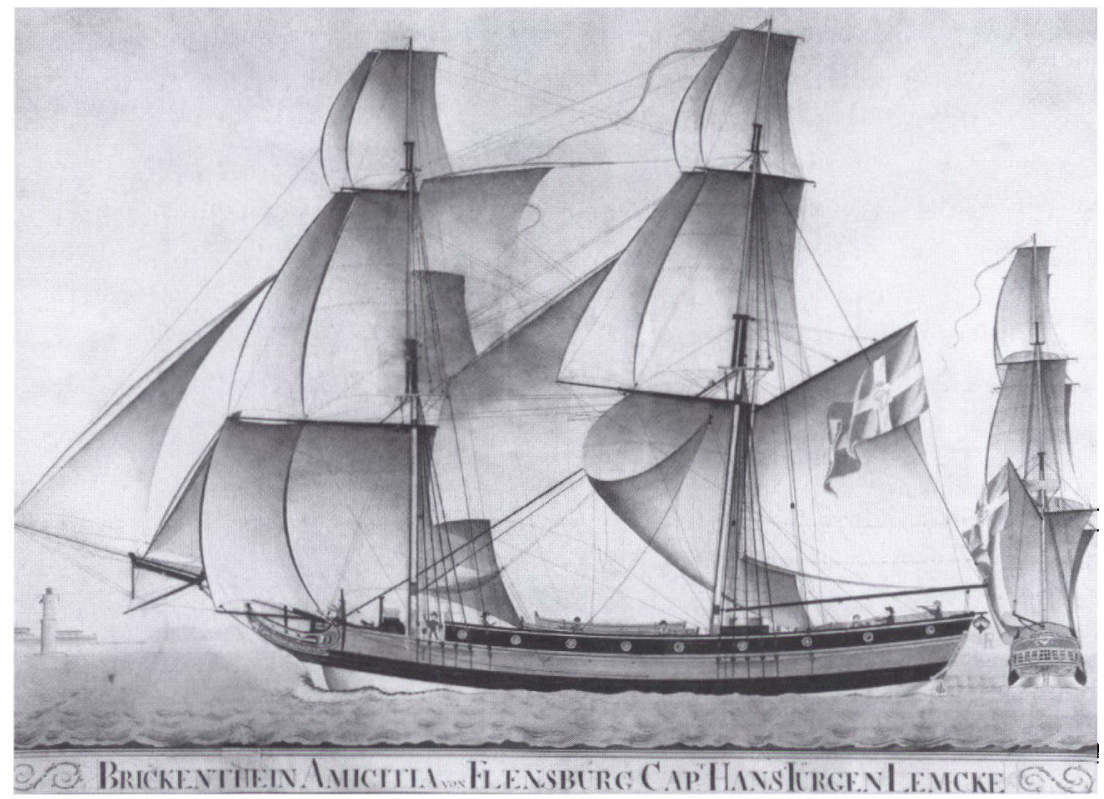

Brigantinen Amicitia af Flensborg for fulde sejl med Christian VIIs monogram i det udbredte Dannebrog. Skibet er tegnet ca. år 1800. Positionen er antydet af fastningseller fyrtårnet $i$ baggrunden. Det kan vare en havn som Livorno eller Marseille $i$ Middelhavet - for netop ruten til Middelhavet var den foretrukne for de store skibe fra Slesvigs byer $i$ perioden fra 1750'erne og frem til 1814. Foto: Arkivet ved Dansk Centralbibliotek for Sydslesvig.

fra Sydeuropa. Det blev bedre, da traktater med de muhamedanske lande i Nordafrika og Tyrkiet fra 1746 gav danske skibe sikkerhed ved sejlads i de sydlige farvande. Den nyvundne sikkerhed blev udnyttet under de europæiske krige i årene fra 1740-48. Fragtraterne ved sejlads med Østersøvarer til Frankrig-Portugal-Middelhavet og retur til Nordeuropa med kolonialvarer eller salt steg. Det gav lyst til at forsøge lykken på de lange sejlruter. Der kom gang i skibsbyggeriet i Flensborg, langs Flensborg fjord, i Ekernførde og på andre byers skibsværfter. Skibene blev sat ind på ruten fra Østersøen og ind i Middelhavet, befragtet af købmænd i Østersøbyerne, i Hamborg, Holland, England, Frankrig eller Sydeuropa. Tonnagen i hertugdømmerne voksede. I 1736 var der i hele Slesvig ca. 250 skibe over 5 læster. I 1745 var tallet 384, altså en vældig stigning.

Den næste højkonjunktur kom under krigene fra 1755/56 til 1763. En kort tid kunne skibe under det neutrale danske flag vise sig på 
fragtfart til Sydeuropa og ind i Middelhavet næsten uden konkurrenter. Risikovillige kapitalejere - købmænd, højtstående embedsmænd og til sidst også enkelte velstående bønder - investerede i store skibe, som blev sat ind på de lukrative ruter. Flensborgs tonnage voksede fra 2.428 kommercelæster i 1754 til 4.058 kommercelæster i 1765. "Fragtpenge er en fast og behagelig indtægt «, udtalte den succesrige Ekernførde-reder Friederich Wilhelm Otte i Ekernførde. Han skabte i disse år et af Danmarks største privatrederier med op mod 25 skibe eller ca. 1.200 kommercelæster. Det var mere end alle skibe i Odense og Århus tilsammen. Hurtigt havde han udnyttet de muligheder, som gemte sig i Middelhavsfarten. ${ }^{8}$

Men fremgangen var konjunkturbestemt. I det sidste krigsår 1763 - bemærkede Nustrup-præsten Johan Arndt Dyssel på rejse gennem Aabenraa "en meget god handel ved mere end hundrede skibe, hvoriblandt er mange meget store, som går til Norge, England, Frankrig, Spanien og ind i Middelhavet. Især har de sidste urolige tider imellem andre nationer givet dem gode fragter, da det danske flag har gået fri og sikker «. Året efter var tonen helt anderledes i en anden beretning: "Nu efter krigen ser det med søfarten slet ud igen. De i krig værende nationer såvelsom de andre behøver nu ingen fremmede skibe. De meste vil drive deres handel selv. Den meste del af sommeren i dette 1764 år har 10 af de største skibe, hvilke udgør et kapital af 60.000 mark og derover, lagt her hjemme uden fortjeneste, og en stor del af dem, der har været ude, har sejlet mere overstyr, end de har fortjent «. ${ }^{9}$ Netop afhængighed af de internationale konjunkturer mere end af vilkårene for den hjemlige vareomsætning er kendetegnende for toppen af hertugdømmernes søfart. En sådan europæisk fart kendte de kongerigske provinsbyer kun som en sjælden undtagelse i denne periode. Det gav bylivet i Slesvig et særpræg.

Handel og søfart delte på en måde Slesvigs byer i to grupper: Mod øst søfartsbyer afhængige af de internationale konjunkturer og derfor præget af ret kraftige op- og nedgange. Mod vest byer med dårlige havneforhold, som ikke gav adgang til at udnytte fragtfartens fordele. Her måtte byerne koncentrere sig om dels eksport af landbrugsvarer fra deres opland og kvæg og heste hentet i Kongeriget og dels import fra Holland og Nordtyskland til deres lokale marked. Også dette gav velstand - men muliggjorde ikke en dynamisk udvikling som mod øst. Derfor de mange beretninger om stilstand i vestkyst-byerne. 


\section{Købmændene - byernes overklasse}

Det er tydeligt, at der i mange slesvigske byer i 1700-årene fandtes købmænd af format. Økonomisk og socialt førte de det store ord. Det bekræftes, når man ser på den formue- og næringsskat på $2 \%$, som blev udskrevet i $1743 .{ }^{10}$ Den dokumenterer, at handelsstanden vejede tungt i Slesvigs byer.

De største formuer lå i Flensborg. De handlende udgjorde her $14 \%$ af skatteyderne. Men de sad på $77 \%$ af formuen. Den tilsvarende formueandel var i Tønder $86 \%$ - stude-, korn- og kniplingshandlerne var rige. I handelsbyen Haderslev med det vidtstrakte og velstående opland rådede de $7 \%$ købmænd over $55 \%$ af formuen. I Aabenraa og Sønderborg var søfolkene mange, og de handlende færre - 10 og 5\%. Men også her fyldte handelskapitalen godt - 44 og $28 \%$.

Alsidighed var kendetegnet for de store købmænd. Jacob Schwennesen i Aabenraa var en typisk storkøbmand for tiden fra 1730 til 1770. Fra landboerne modtog han kød og smør, oste, mursten, brænde og tusindvis af alen hjemmegjort lærred. Det blev som oftest afskibet til Norge, København eller måske provinshavne i Kongeriget. I oplandet forpagtede han retten til at levere $ø l$ og brændevin, og helt ud på vestkysten solgte han importvarer fra Østersøregionen. ${ }^{11}$ Hos kollegaen Peter Raben i Haderslev frem til 1774 var sortimentet det samme, og købmanden fungerede som bank for sine kunder. Ved sin død havde Raben samlet over 400 obligationslån ydet til borgere og bønder i de omliggende herreder - i alt 32.000 rdl. $^{12}$

Begge købmænd investerede også i skibsparter. Sådan gjorde alle købmænd i Slesvigs driftige søfartsbyer. Det skete på anpartsbasis, for på den måde deltes risikoen, og det blev muligt at øge engagementet hurtigt under de gode konjunkturer 1740-48 eller 1756-63. Kun i Ekernførde møder man rederier i moderne forstand, ejet af en enkelt eller nogle få redere. I Aabenraa var ejerformen ofte skiftende partnerskaber af skipperkøbmænd. I Sønderborg stod en meget bred kreds - også landboer - bag skibene. I den største havneby Flensborg blev de mange skibe finansieret af skiftende købmands-anpartsselskaber. Hovedrige handelshuse kunne let have parter i 20 skibe. Varehandel med artikler af mange slags, skibsfart for egen regning og fragtfart gik op i en højere enhed. En meget stor del af befolkningen i østkystens havnebyer var afhængige af søfarten, som søfolk, handlende, håndværkere og investorer. ${ }^{13}$ 


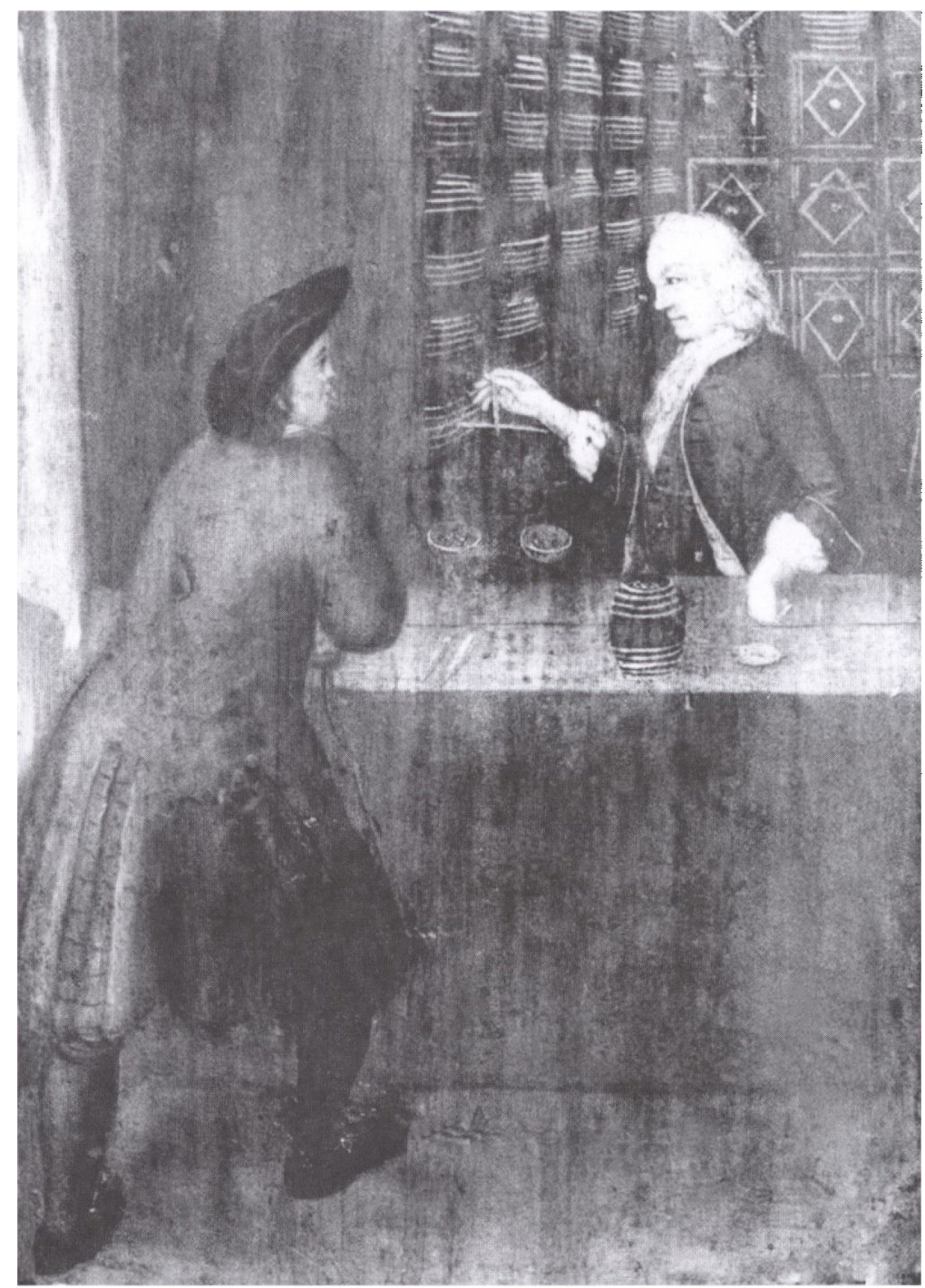

Et blik ind $i$ kobmandens bod, hvor kunden onlhyggeligt folger afoejning af de kostbare varer. I alle de slesvigske byer fandtes siidanne kobmandsforretninger. Nogle handlede iser med alenvarer, som kunne salges efter mall (tekstiler), andre med kortevarer, dos. varer som blev solgt stykkevis (isenkram og galanterivarer), andre med urtekram (kolonialvarer). Nogle koncentrerede sig om de "grove varer" - salt, hør, stokfisk, tjare, tommer, jern m.v. Ofte var udvalget dog ikke nar så snavert som $i$ en senere tids specialforretninger. En blanding af forskellige brancher var snarere det almindelige. Detalje af motiz pa linnedskab fra herregarden Hesselmed ved Esbjerg. Foto: Esbjerg Museum. 
I vareomsætningen var basale varer som hør, salt, tømmer og jern af afgørende betydning. Tekstilhandelen var også vigtig. På vestkysten fremstilledes uldtøj eller vadmel, på midtlandet huer og strømper og næsten overalt hør- og blårlærred. En del kom ud $\mathrm{i}$ handelen, ofte gennem købmænd, der som forlæggere sørgede både for råvarerne og videresalget. En del blev eksporteret til Kongeriget. Men der var også en betydelig efterspørgsel efter fremmede tekstiler. De kom næsten alle sydfra. Nogle få købmænd drog til messe i Braunschweig eller Leipzig eller importerede direkte fra Schlesien, Westfalen, Brabant eller andre tekstilcentre. Meget kom fra købmænd og kræmmere i Hamborg, Altona og Lübeck. I Flensborg, Husum og andre byer holdt de lagre, og de besøgte årsmarkederne i Flensborg, hvor købmænd fra det meste af Slesvig gjorde indkøb. Flere store Flensborghandelshuse lagde særlig vægt på tekstilhandel, direkte eller som grossister over for købmænd i nabobyerne mod nord. ${ }^{14}$ Afhængigheden af leverancer og kredit hos grossisterne i Altona og Hamborg var stor.

\section{Håndværkere og markeder}

Søfarten vejede tungt, og alligevel var håndværkerne overalt kærnen i byernes borgerskab. For Husum er beregnet, at de i 1769 udgjorde $51 \%$ af befolkningen, og lignende var fordelingen andetsteds. Skræddere, skomagere og bagere var som regel de fleste. ${ }^{15}$

Lavsreglerne regulerede håndværket $\mathrm{i}$ detaljer. I de mindre byer var mange håndværkere ikke sammensluttet $\mathrm{i}$ lav, eller de var knyttet til lav i de større byer - hattemagerne i Aabenraa således til lavet i Itzehoe i Holsten næsten $200 \mathrm{~km}$ borte. Nogle lav var lukkede, dvs. de tillod kun et fast antal "amtsmestre", som naturligvis med alle midler søgte at fastholde deres privilegier og hindre indsættelse af "frimestre " uden for det lukkede lavs rækker. Denne stive struktur medførte ofte gnidninger mellem håndværkerne på den ene side og på den anden side staten, bystyret eller de handlende, som ønskede en mere liberal og fleksibel tilpasning af udbud og efterspørgsel. F.eks. skabte Flensborgs handel et særlig stort behov for bødkertønder, og behovet skiftede i forhold til omsætningens op- og nedgange. Men bødkerlavet var lukket, og de 7 faste amtsmestre og deres svende kunne have svært ved at øge produktionen i opgangstider. Når handelen gik frem, klagede købmændene hyppigt over mangel på 
tonder, men lavsmestrene gav nødig nye folk del i næringen. Kun under særligt gode konjunkturer, som f.eks. omkring 1780, lykkedes det at øge antallet af amtsmestre. ${ }^{16}$ En egentlig liberalisering af lavssystemet kom først $\mathrm{i}$ begyndelsen af det følgende århundrede.

Byhåndværkerne kæmpede også mod landhåndværkerne. I 1711 fastslog flere forordninger for begge hertugdømmer, at der inden for en afstand fra en købstad af 3 mil på gestlandet ikke måtte drives handel eller findes håndværkere, lige bortset fra hjulmager, grovsmed, skrædder og skomager. I marsken, hvor vejene hyppigt var oversvømmede og forbindelsen mellem by og land altså særlig dårlig, var grænsen 2 mil. De tilladte landhåndværkere måtte kun arbejde indensogns og måtte ikke opsøge årsmarkederne. Ulovlige håndværkere og handlende skulle slå sig ned $\mathrm{i}$ en by eller flække. ${ }^{17}$

Lokalt blev loven fulgt op af særregler. I Haderslev blev »de forbudte distrikter « nøje beskrevet i 1744. Inden for 3 mil fra byen måtte ingen bonde drive købmandsskab med landbrugsvarer, og langt de fleste varer skulle erhverves $i$ byerne. Uden for den nævnte radius blev retten til at levere høkervarer og $ø \mathrm{l}$ og brændevin til kroer og fester bortforpagtet, som regel til bykøbmænd. De forpagtede kroerne $i$ byens opland og sikrede sig dermed ret til at afsætte høkervarer, vin og brændevin i distriktet. Ølbrygning og brændevinsbrænding var mange borgeres vigtigste næring, og ved at forpagte kroer og høkerier på landet søgte borgerskabet at sikre sig afsætningen til oplandet. ${ }^{18}$ Men lovene forblev som regel døde bogstaver. I utallige skrivelser klagede byerne over omløbende landkræmmere, ulovlig brygning, brændevinsbrænding, høkeri og håndværk på landet.

Håndværkerne arbejdede ikke kun for de lokale forbrugere mange producerede også for et ukendt, fjernt marked. I Flensborg modtog knapmagerne ordrer på i tusindvis af knapper til militærets uniformer, og vævere og husflidsarbejdere havde store militærleverancer, ofte via byens tekstilkøbmænd. Fra Haderslev kunne byens vævere i 1750'erne sende skibsladninger på titusinder alen lærred og drejl til København. Håndværkerne eller deres koner besøgte markeder $\mathrm{i}$ Jylland og på de danske øer ${ }^{19}$ - på den måde hang den enkelte bys økonomi nøje sammen med omverdenen - det nære eller mere fjerne.

Markederne var vigtige for vareomsætningen. Hver by havde årligt to til tre »årsmarkeder«, som lokkede handlende til fra nær og fjern. Til Nordslesvig kom mange handlende fra Jylland og Fyn, længere 

gav prestige. I 1755 grundlagde en greve, en baron og nogle borgerlige sammen med den rige reder- og købmandsfamilie Otte fra Ekernførde en fajancefabrik i Slesvig, og snart var der en hel række virksomheder. De første sukkerraffinaderier kom til Slesvig i disse år, som følge af sukkerimportens frigivelse i 1754, nemlig i Flensborg, Husum og Frederiksstad.

Vigtigst var de mange forsøg på tekstilområdet. I Slesvig by startede adelige og borgerlige kapitalejere i 1755 med statsstøtte en fabrik for kniplingstråd, og året efter prøvede man at fremstille luksushørlærred. I Ekernførde drev familien Otte det særlig vidt. I 1761/62 byggedes et stort uldmanufaktur, hvor der på 32 vævestole blev fremstillet forskellige slags uldstof, huer og strømper.

Kildernes beretning om de tidlige "manufakturer" og "fabrikker" er ganske lang. Men ordene er misvisende. Det var ikke industri i moderne forstand. I Ekernførde kunne de rige købmænd bekoste opførelse af store centrale produktionslokaler til 30 vævere og op mod 80 tekstilarbejdere samt 80 mand i fajancefabrikken. Så store anlæg var undtagelsen. I de fleste tilfælde foregik arbejdet decentralt som "forlagsindustri« på grænsen af husflid. Garnet blev spundet af hundredvis af hjemmespindere, og væverne arbejdede ofte hver for sig eller få sammen, som selvstændige håndværkere, evt. med forlæggerkøbmanden som forbindende led. Større centraliserede virksomheder voksede først frem fra århundredets slutning. ${ }^{22}$

De industrielle forseg havde hyppigt en social dimension. Garn var en mangelvare, og overalt blev klaget over tiggeri, fattigdom og arbejdsløshed. Derfor var det nærliggende at etablere et samarbejde med fattigvæsenet. Købmandsfamilien Otte i Ekernførde foreslog i 1762 , at alle fattige, som fik understøttelse, skulle spinde garn til familiens virksomheder - eller miste understøttelsen. Sådanne ideer var velsete $\mathrm{i}$ regeringen, og mange byer måtte efter pålæg fra centraladministrationen $\mathrm{i}$ gang med at etablere fattigspinderier. ${ }^{23}$ Resultaterne blev ikke imponerende - men forsøget på at benytte fattigfolk i tekstilindustrien blev gentaget gang på gang senere i århundredet. I tugthusene i Glückstadt, Neumünster, Rendsborg og Flensborg blev der spundet og vævet, og huer, vadmel, hestedækkener eller finere tøj herfra udgjorde en væsentlig del af tekstilhandlernes tvungne omsætning af indenlandske varer.

Meget blev forsøgt - og meget mislykkedes, for kapitalen og markedet var begrænset. De dyre tekstiler og fajancer fra virksomhederne 


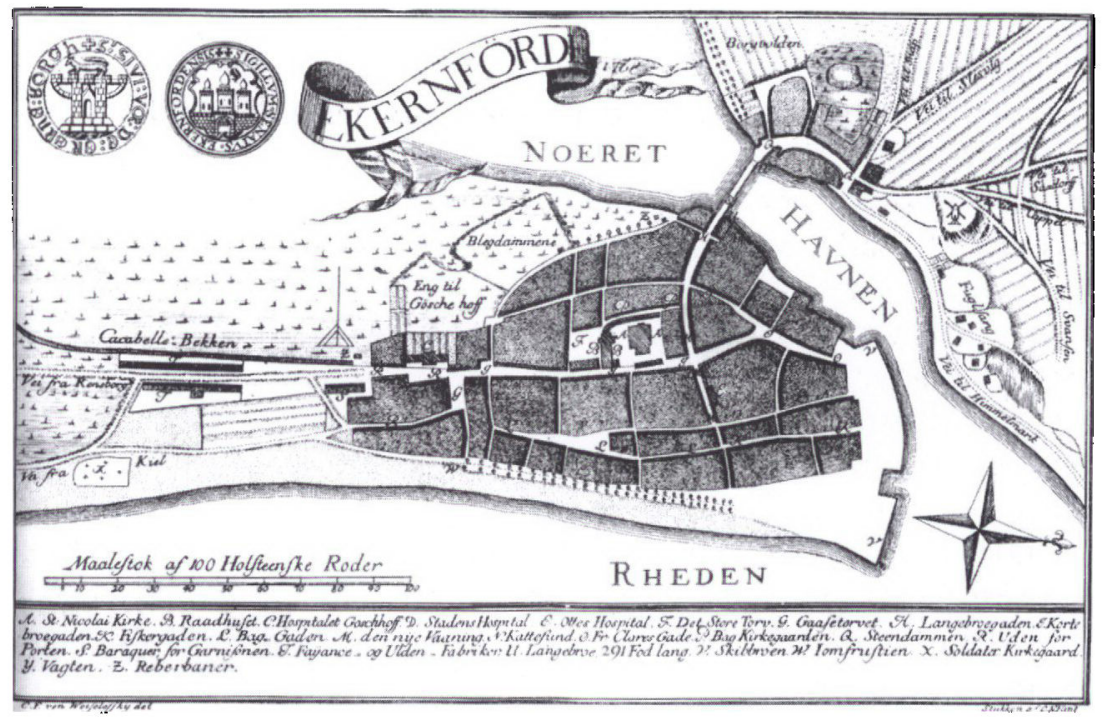

Bykortene i Pontoppidans Danske Atlas giver et godt indtryk af kobstæedernes gadenet og mest markante bygninger $i$ sidste halvdel af 1700-tallet. Pà kortet over Ekernforde fra 1768 ser man yderst til venstre ved signaturen $T$ pa begge sider af vejen mod Kiel-Rendsborg de to markante fabriksbygninger, som var indrettet kort forinden af byens rige reder og købmand Fr. W. Otte. I bygningen overst var der uldmanufaktur, $i$ bygningen derunder fajancefabrik. Dette anlag var både ved sit omfang og med sit centraliserede fabrikskompleks ganske atypisk for tiden. Ellers havde tidens "industrielle « eksperimenter langt mindre omfang og byggede $i$ tekstilbranchen mest på spindere og vavere, som arbejdede spredt.

i Slesvig og Ekernførde var svære at sælge, selv om staten prøvede at hjælpe med indførselsforbud og toldlettelser. Den slags kunstige virksomheder svandt hen, når kapitaltilførsel fra købmands-fabrikanterne eller staten udeblev. Afsætning var der kun for de mere dagligdags varer. Kniplingstrådfabrikkerne i Slesvig, Tønder og Løgumkloster havde nogen afsætning hos de mange kniplersker i Tønder og Haderslev amter. Tobak blev spundet i de fleste byer. Også sukkerraffinaderierne i Flensborg og de hundredvis af brændevinsbrænderier havde stor afsætning, i hertugdømmerne og i Norge. Men ellers stod manufakturer og såkaldte fabrikker i hele 1700-tallet på svag fod. Ikke »industri«, men søfart og handel var de kapitalskabende erhverv i byerne. 


\section{Bystyre}

Den kommunale administration var præget af betydelige forskelle fra by til by. I hver by dannede en lille kreds af såkaldt »deputerede borgere « en slags kommunal repræsentation for borgerskabet. Antallet varierede: 12 i Aabenraa og Slesvig, 16 i Haderslev, Sønderborg og Tønder, 24 i Flensborg. De deltog i skatteligning og godkendte byregnskabet, og de beklædte på skift hvervet som bykasserer eller regnskabsfører for fattigkassen. Fra samme kreds besatte man også byens andre tillidshverv, f.eks. som kirkeværge eller hospitalsforstander. De 4-6 rådmænd udgjorde sammen med en eller flere borgmestre det egentlige bystyre, eller "magistraten «, som det hed. De dannede byens domstol, rådstueretten, og sad ligesom borgmestrene på livstid.

Bedrestillede håndværkere kunne få plads i deputeretkollegiet, men købmænd dominerede, og $\mathrm{i}$ rådet havde købmændene nærmest monopol på pladserne. Snævre familiebånd knyttede rådmænd og deputerede sammen - ikke blot inden for den enkelte by, men også byerne imellem. Mange steder blev borgmesterposten langt ned i århundredet beklædt af de mest velhavende købmænd. Alle poster i det kommunale styre var i princippet æreshverv, kun lønnet med sportler eller anselige skattelettelser. Disse poster kunne være en byrde for travle forretningsfolk, og gang på gang søgte velhavende købmænd at købe sig fri for de borgerlige ombud.

I bystyret indgik elementer af lokalt selvstyre og borgerindflydelse. F.eks. valgte samtlige grundejere i Haderslev ved flere lejligheder borgmesteren ved direkte, skriftlig afstemning. Mere karakteristisk var dog de aristokratiske træk. Rådmændene supplerede oprindelig sig selv fra de deputeredes rækker og valgte måske borgmesteren, evt. efter forslag fra de deputerede. Rådet valgte også nye deputerede efter dette kollegiums forslag, eller de deputerede var selvsupplerende. ${ }^{24}$

Det kommunale selvstyre var imidlertid ikke så uindskrænket, som ovenstående lader formode. Det aristokratiske princip bar i sig kimen til sociale spændinger, og det førte til indgreb fra statsmagten. Sidst i 1600 'årene opponerede borgerskabet i næsten alle byer mod rådsaristokratiets styre og dets forvaltning af skatte- og regnskabsvæsen, og staten greb ind.$^{25}$ Resultatet blev en styrkelse af borgerskabet eller de deputerede over for rådet, og især en gradvis vækst i statens ensrettende indflydelse på bekostning af det lokale selvstyre. Valg af råd- 


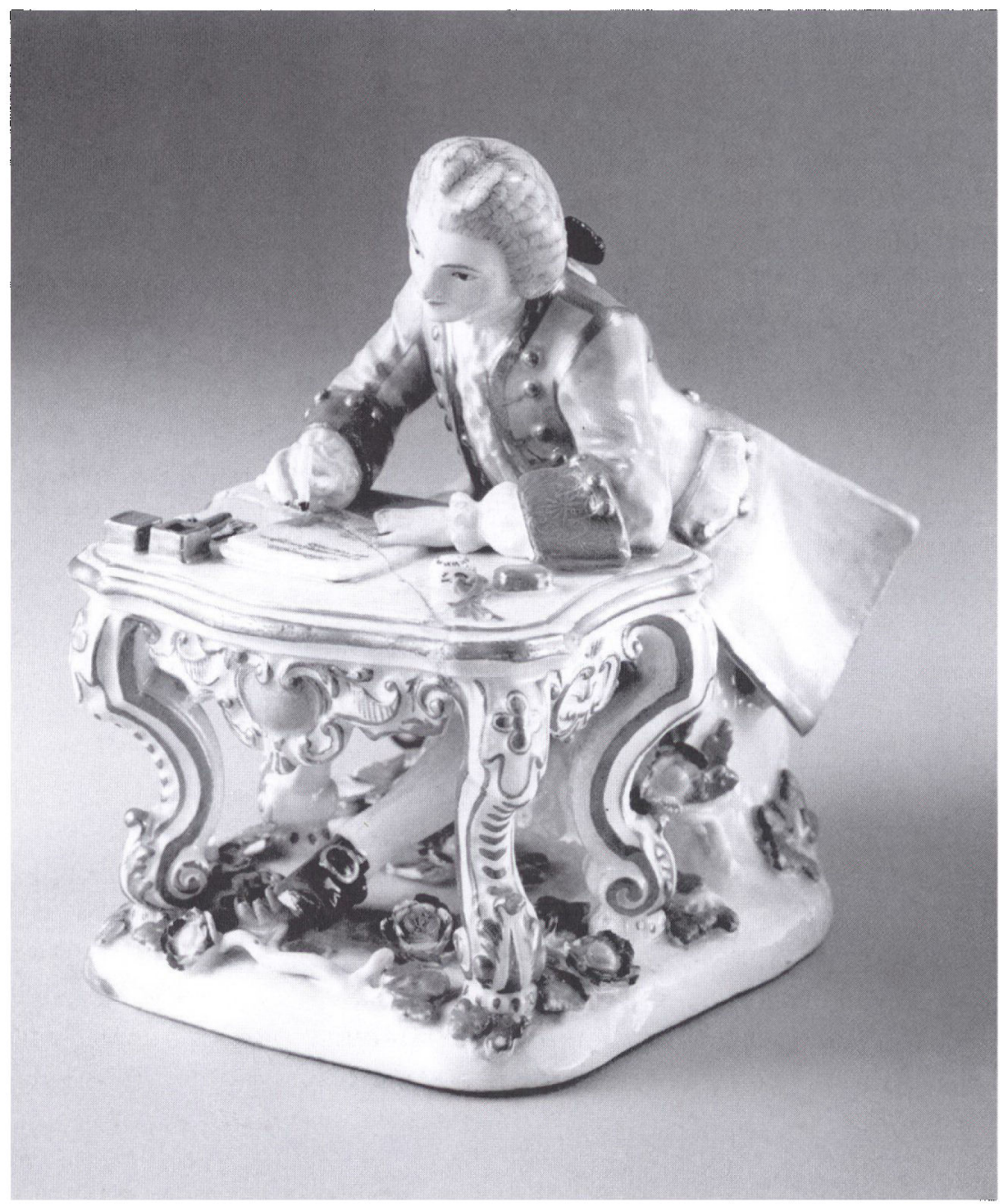

Kobmanden ved sit skrivebord. Alle kobmxnd var afhængige af et velfungerende bogholderi for at kunne holde styr på kontakt med leveranderer og kunder og på indog udbetalinger. De største købmænd havde ansat kontorbetjente til at varetage den omfattende breoskrivning og regnskabsføring. Købmændene var med deres gode kontakter, skrive- og regnskabskyndighed og velstand også selvskrevne til at deltage $i$ byens styre - som medlemmer af deputeretkollegiet, som rådmænd og måske som borgmestre. Meissen-porcelænsfigur i Museum fiur Kunst und Gewerbe $i$ Hamborg. 
mænd eller borgmester krævede herefter kongens godkendelse. Gang på gang kom der strid mellem en by og statsmagten om valg af rådmænd eller borgmester, og kongelige udnævnelser blev mere og mere almindelige i 1700årene. Byernes selvstændige valg af øvrighed udviklede sig til en forslagsret - godkendelse og stadfæstelse lå i centraladministrationen. Ikke sjældent pressede staten sin kandidat igennem mod lokale ønsker.

En af følgerne var, at studerede folk gradvis overtog borgmesterposten fra de selvlærte købmænd. Stigende lønudgifter måtte borgerne tage med i købet, men stadigvæk var den kommunale administration uendelig lille. En jævnstor købstads typiske lønkonto omfattede

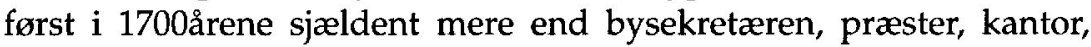
organist, fattigfoged, bytjener, vægter og skarpretter.

Kontrollen ovenfra blev voksende: I 1720'erne kom byerne under tilsyn af den lokale amtmand i egenskab af »bypræsident «, indtil statholderen fra 1731 overtog opgaven. I 1736 blev alle slesvigske byprivilegier indkaldt til revision. Fra 1741 skulle byerne indhente statholderens tilladelse til optagelse af nye lån. Fra 1756 skulle byregnskaberne indsendes til statholderen, fra 1772 til Rentekammeret i København. ${ }^{26}$ Tendensen er tydelig - dog blev der ikke tale om en systematisk ensretning eller tilsidesættelse af det lokale styre, således som i Kongeriget. "Statholderen « på Gottorp slot forte ikke et så skarpt tilsyn med byerne som »stiftamtmændene« nord for Kongeåen. Hertugdømmernes byer forblev mangfoldighedens landskab langt op i det følgende århundrede.

\section{Tendenser i byudviklingen 1700-1806}

Ovenfor er fremhævet, at de store slesvigske byer gennem handel og søfart indgik $i$ et tæt netværk med omverdenen. Mere end byerne $i$ Kongeriget var de søfarts- og handelsbyer. Derfor var de i særlig grad afhængige af internationale konjunkturer. Denne afhængighed medførte over tid ændringer, som kan aflæses i byernes befolkningstal og skibstonnage og i deres indbyrdes rangorden som lokale handelscentrer inden for Slesvig. Op- og nedgange prægede i særlig grad østkystens havnebyer - de øvrige byer dannede et mere stabilt element.

Generelt var Flensborg den dominerende handels- og søfartsby. Alligevel kan der konstateres væsentlige forskydninger $\mathrm{i}$ byernes indbyrdes rangordning. Under krigene i Europa 1688-97 og i årene 1701- 
1709 nød byerne godt af, at den danske konge og den gottorpske hertug forholdt sig neutrale. Skippere og redere fra ikke neutrale områder flyttede til de neutrale byer for herfra at fortsætte skibsfarten. I årene 1709 til 1713 gjaldt neutraliteten kun de gottorpske områder det blev til fordel for byerne Aabenraa og Ekernførde. ${ }^{27}$

Disse byers position blev udbygget efter fredsslutningen $1721 \mathrm{og}$ frem til 1750'erne. Mens Flensborg stagnerede, oplevede de øvrige østkystbyer fremgang. De stillede skibe til rådighed for købmænd og kompagnier i København, og frem til 1740'erne sejlede mange skibe på Sverige, Gotland og Kalmar. Især Aabenraa gik i disse år frem med stormskridt. Indbyggertallet voksede fra ca. 1250 i 1721 til op mod 3000 i 1753, skibsflåden voksede fra 779 kommercelæster i 1705 til 1109 kommercelæster i 1710. I årene fra 1729 til 1748 blev den næsten tredoblet (fra 1643 kommercelæster til 4332 kommercelæster), og skibsbyggeriet gik frem. En kort tid overgik Aabenraa Flensborg som søfartsby. Det skyldtes ikke så meget handel med varer til og fra hjembyen som den nævnte fart på fremmede havne, på Gotland/Sverige og England og fragter for kompagnier og købmænd i København til Island og Finmarken og Nordeuropa. I Ekernførde skete noget lignende. Byens tonnage fordobledes fra 1720 til 1740. Også Sønderborg nød fremgang. Blandt de slesvigske byer indtog den en forsteplads $i$ besejlingen af København og Norge. ${ }^{28}$

Fra 1740erne blev fremgangen modvirket af svensk beskyttelseslovgivning. Love af 1724, 1726 og 1744 begunstigede svenske skibe på fremmedes bekostning.

Til gengæld kom der nye muligheder fra en anden kant. Det skyldtes ikke mindst krigsårene 1740-48 og 1756-63. Nu engagerede byerne sig i den store europæiske fragtfart. Udviklingen bliver tydelig, hvis man ser på antallet af skibspas, som centraladministrationen i København udstedte til danske skibe i europæisk langfart. I årene 1747-71 udstedtes i alt 949 søpas til skibe fra de tre slesvigske byer Flensborg, Aabenraa og Ekernførde til sejlads på Middelhavet - samtlige provinsbyer i Kongeriget Danmark kunne kun mønstre 100 pas og København $398 .{ }^{29}$ 
Søpas udstedt til danske skibe til besejling af Middelhavet: ${ }^{30}$

\begin{tabular}{lccc}
\hline & $1747-71$ & $1778-92$ & $1793-1807$ \\
\hline København & 398 & 699 & 1192 \\
Danske provinsbyer & 100 & 149 & 333 \\
Flensborg & 415 & 658 & 1107 \\
Aabenraa & 296 & 288 & 268 \\
Ekernførde & 238 & - & - \\
Sønderborg & - & 94 & 120 \\
\hline
\end{tabular}

Fra slutningen af 1760 'erne begyndte en ny fase i udviklingen. Landbruget blev moderniseret, priserne steg, og befolkningstallet begyndte at vokse. Det var faktorer som bredt fremmede alle byers udvikling. Den generelle vækst i samfundet var det afgørende for byerne på vestkysten, hvor havneforholdene ikke muliggjorde deltagelse i den store søfart og handel. Blandt vestkystbyerne var det kun Tønning, som mærkede følgerne af de storpolitiske konjunkturer. Efter åbningen i 1784 af den nye vandvej Ejderkanalen fra Holtenau ved Kiel over Rendsborg til Tønning fik byen en vigtig position på den ny internationale vandvej. Alle skibe skulle anløbe Tønning og betale told, der blev bygget et stort pakhus. Senere oplevede byen fra 1803 en feberartig vækst. Ved den engelske blokade af Elben 1803-05 blev Tønning en kort tid vigtigste anløbshavn for skibe til Hamborg og Altona. I 1803 var indbyggertallet 1.923, i 1807 ca. 5.760. I de følgende år nød byen godt af smughandel til omgåelse af kontinentalspærringen. ${ }^{31}$

Husum udviklede sig stabilt. Byens få større skibe sejlede fra Altona. Den søværts forbindelse til Altona, Hamborg og Holland blev varetaget af et betydeligt antal småfartøjer. Denne fart og den meget betydelige omsætning af stude og heste gav basis for et stigende befolkningstal fra 1769 til 1803. Velstand prægede også Tønder, den nordligste købstad på vestkysten. Al søværts kontakt vestpå foregik over de nærliggende ladepladser Højer og Rudbøl. Opkøb af stude i Slesvig og Danmark til opfedning og videresalg gav store indtægter. Også de mange kniplingshandlere, som finansierede fremstilling og eksport af de kostbare kniplinger fra et stort opland omkring byen bragte betydelige indtægter, uden dog at øge byens indbyggertal.

For vestkystbyerne var den almindelige vækst i samfundet det afgørende. På østkysten derimod mærkedes mere påvirkningen af de 
skiftende, politisk betingede konjunkturer. De store krige: den amerikanske uafhængighedskrig 1778-1783 og revolutionskrigene fra 1792 indtil 1807 øgede efterspørgslen på skibe fra de neutrale dansk-slesvigske byer, og fik fragtraterne til at stige. Det gav muligheder - og de blev udnyttet på østkysten i forskellig grad. Vinderen blev Flensborg, som nu evnede at distancere alle de øvrige byer.

Den nordligste by Haderslev var handicappet af den dårlige havn oplandets bønder foretrak at søge til Aabenraa og Flensborg. Stærk konkurrence blev påført af brødremenighedskolonien Christiansfeld grundlagt 1771 lige nord for byen. Udstyret med fulde rettigheder til handel og håndværk påførte koloniens dygtige håndværkere og handlende den gamle købstad betydelig konkurrence. Som handelsby blev Haderslev trængt tilbage. Fremmede varer kom fra grossister i Flensborg og Lübeck - eller fra Hamborg, evt. med Højer og Ribe på vestkysten som mellemstationer. Først efter 1830, da sejlrenden blev uddybet, oplevede havnen i Haderslev en voksende benyttelse. Resultatet var stagnation i Haderslev sidst i 1700-årene, dog med velstand bygget på tidens almindelige fremgang, omsætning til det vidtstrakte bagland og de mange gennemrejsende, byens mange embedsmænd og en stor militær garnison. ${ }^{32}$

Aabenraa stagnerede efter 1763. Handelen på Sverige og England blev besværliggjort af de to landes søfarts- og handelslovgivning. Til gengæld benyttede byens skippere sig af de ekstraordinære konjunkturer 1778-83 og 1792-1806. Aabenraa-skibe sås i farten på de lange ruter fra Østersøen til Middelhavet. Men flåden nåede aldrig op på størrelsen fra 1750'erne, beskæftigelsen for søfolk faldt fra o. $450 \mathrm{i}$ 1740 'erne til ca. 300 sidst $\mathrm{i}$ århundredet. Flåden stagnerede på mellem 2000 og 2300 kommercelæster, og indbyggertallet lå ligeledes fast (1769: 2.701, 1803: 2.834). Byens andel af hertugdømmernes besejling af Middelhavet faldt fra $17 \%$ i perioden $1747-71$ til $9 \%$ i årene $1793-$ $1807 .^{33}$

I Sønderborg var dynamikken måske noget større. Udgangspunktet var den gode havn, fortrinlig beliggenhed i forhold til handel og sejlads på Danmark og Østersøen. Mange mindre skibe sørgede for omsætning af landbrugsvarer og mursten fra og til hele Als-Sundeved-området. Hertil kom stigende deltagelse i den store udenrigsfart, i forhold til Aabenraa med flere og noget mindre skibe. 1778-1807 tegnede Sønderborg sig for $4-5 \%$ af hertugdømmernes Middelhavssejlads. Men også her gjorde konkurrencen fra Flensborg sig gældende. ${ }^{34}$ 
Mod sydøst blev Ekernførde fra slutningen af 1760 'erne trængt helt tilbage som søfartsby. Oplandet var begrænset, og fra 1784 medførte anlæggelsen af Ejderkanalen, at transitfunktionerne $i$ forhold til Rendsborg faldt bort. Oplandets godser foretrak at sælge deres varer og forsyne sig i Rendsborg og Kiel. Byens tonnage svandt ind, næringen blev håndværk, fremstilling af øl, malt og brændevin. Periodens generelt stigende velstand skabte en vis byvækst, men vigtigst var, at byen med oprettelsen af en statslig militær plejeinstitution »Christianspflegehaus« opnåede en tilvækst på op mod 400 personer.

Regeringsbyen Slesvig klarede sig bedre og gennemgik en solid vækst næsten på højde med Flensborgs, fra et indbyggertal på 5.629 i 1769 til 7.823 i 1803 og til lidt over 11.000 i 1835-45. Det skyldtes hverken søfart eller omsætning i forhold til oplandet. Besejlingen af havnen gik ganske vist frem, da anløbsforholdene blev forbedret $i$ 1762,1778 og 1783, men stadig kunne Slesvig slet ikke gøre sig gældende som søfartsby. Fremgangen skyldtes især byens stilling som administrations- og regeringsby. ${ }^{35}$

\section{Flensborg i centrum}

Fra 1778 til 1806 blev væksten således især koncentreret i Flensborg. Byen udviklede sig til det dominerende søfarts- og handelscentrum, overordnet alle de øvrige byer. Fjordbyen med den gode beliggenhed midt i Slesvig og den fremragende havn tiltrak sig broderparten af udviklingen. I 1769 blev byens befolkning talt til 6.842, i 1803 angives 10.666. Et øjebliksbillede 1799 taler om en befolkning på måske 15.000, hvis man medregnede hundredvis af daglejere fra omegnen på dagsbesøg, garnisonen og indrullerede matroser samt forstæder. Den rivende fremgang i disse år fremgår af et udpluk af detaljer: i 1795 blev forstaden Neustadt frigivet til bebyggelse og indlemmet. 200 brænderier producerede brændevin til afsætning i oplandet, Danmark og Norge, af affaldet blev 4.000 stk. hornkvæg opfedet. Flensborg var eneste by, som i datidens forstand kunne kaldes "industriby «. Vigtigst var 5 sukkerraffinaderier, 40 tobaksfabrikker, 2 stivelsesfabrikker, 2 sæbesyderier, og dertil lysestøberi, flere farverier, garverier, papirmølle, skibsværfter og rebslagerbaner samt sejldugsfabrikker. Markederne i byen trak kunder til fra det meste af Slesvig, og handlende fra Flensborg fyldte godt på markederne i nabobyerne. Tonnagen boomede. Fra 126 skibe med 3.986 kommercelæster i 1777 nåede den i 1806 
Byvæksten blev således mere jævnt fordelt end i årene forud. Det skyldtes også, at landbruget fra 1830'erne oplevede ny fremgang oven på efterkrigsårenes landbrugskrise. Det virkede jævnt tilbage på byerne. Størst fremgang oplevede Haderslev. Byen havde så at sige ingen skibe og havde derfor heller ikke lidt tab ved opbringelser i krigsårene. Byens basale næring - handel og håndværk- kunne fortsætte uændret efter krigen. I 1830 blev havnen udbedret og det gav mulighed for skibsbyggeri, anlæggelse af jernstøberier og andre industriprægede virksomheder. Omsætningen til det store opland kom for alvor i vækst. Indbyggertallet steg fra 3.635 i 1803 til 6.156 i 1840 . Byen oplevede den største procentvise vækst blandt alle byer i Slesvig. ${ }^{37}$

Områdets regeringscentrum Slesvig gik også frem, fra 7.823 indbyggere i 1803 til 11.551 i 1845 . Det skyldtes øget omsætning og efterspørgsel som følge af nye regeringskontorer, nyanlagte sygehuse og garnison. ${ }^{38}$ Der mærkedes tilsvarende fremgang i små havnebyer, som nød godt af landbrugets fremgang og den stigende velstand. Det gjaldt bl.a. Kappel og Arnæs på østkysten.

De største omstillinger var nødvendige i de store søfarts- og handelsbyer. For alle østkystbyerne, som havde satset på den konjunkturfølsomme europæiske langfart, gjaldt, at deres flåder blev reduceret til under halvdelen. Vigtige fartområder - Middelhavet og Norge faldt bort, og nye mål måtte findes. I Aabenraa indledte byens søfartskredse samarbejde med redere i Hamborg om store skibe, som gik i fragtfart for fremmed regning, især på Syd- og Mellemamerika og senere Kina-Indien. På ganske få år blev tilbageslaget som følge af krigsårene afløst af ny, imponerende fremgang. I 1824 var flåden vokset til førkrigsstørrelse, i 1848 var den mere end fordoblet, til 4.776 kommercelæster. I 1850'erne havde Aabenraa nået førstepladsen blandt søfartsbyerne i Slesvig - forud for Flensborg. Det gav næring til et betydeligt skibsbyggeri. Indbyggertallet steg fra 2.834 i 1803 til 4.086 i 1845 . Det var en udvikling lige så markant som i tiden 1721$1750 .{ }^{39}$ I Sønderborg engagerede byens storkøbmænd, redere og skibsbyggere sig på samme måde i oversøisk fart fra 1820'erne til hen $\bmod 1870$.

Dermed er allerede sagt, at Flensborg ikke genvandt sin gamle dominans fra den florissante førkrigsperiode. Skibsflåden svandt ind til under halvdelen. I udpræget grad satsede byen nu på sejlads og handel på Dansk Vestindien. En kort overgang fik Flensborg forspring 'for København og danske byer - men fra 1830'erne blev Flensborg 
trængt tilbage fra Vestindien $\mathrm{i}$ forhold til både danske byer og de langt stærkere kolleger i Hamborg. Ubønhørligt mistede Flensborg terræn som skibsfartsby og international handelsby. Stadig flere varer kom direkte fra Hamborg, og Kiel i Holsten blev en alvorlig konkurrent. Andre byer gjorde sig fri af Flensborg som mellemhandler. I 1850 'erne var Flensborgs tid som overordnet handelscentrum i Slesvig ved at være forbi. Større betydning for byen fik i stedet de mange statslige myndigheder og deres embedsmænd, som efter krigen 184850 fik hjemsted i byen. ${ }^{40}$

Væksten efter 1830 fik dermed en større bredde end $i$ den periode, hvor Flensborg havde været den ubestridte hovedby - årene omkring 1800. Denne fase varede frem til 1864, da Slesvig blev skilt fra Danmark og kort efter en del af Kongeriget Preussen. Dette medførte igen voldsomme omstillingskrav for byerne. En ny fase i deres indbyrdes udviklingshistorie blev indledt.

\section{LITTERATUR}

Andersen, Dan H. 2000. The Danish Flag in the Mediterrancan. Shipping and Trade, 1747-1807. Copenhagen. Ph.d. thesis. University of Copenhagen.

Becker-Christensen, Henrik 1988. 'Protektionisme og reformer $1660-1814^{\prime}$. I: Dansk toldhistorie II. Kobenhavn: Toldhistorisk Selskab.

Beiträge 1967. Beiträge zur historischen Statistik Schleswig-Holsteins. Kiel: Statistisches Landesamt Schleswig-Holstein.

Dyssel, Johan Arndt 1924-25, 'Iagttagelser paa en Rejse gennem Nordslesvig i 1763'.Sønderjydsk Maanedsskrift, 171-173.

Fangel, Henrik 1975. Haderslev bys historie 1800-1945. Haderslev.

Feldbæk, Ole 1982, Danmarks historie Bind 4. Tiden 1730-1814. Kobenhavn: Gyldendal.

Gregersen, H.V. 1961. 'Tiden 1660 til $1720^{\prime}$. I: Johan Hvidtfeldt og Peter Kr. Iversen (eds.): Aabenraa Bys Historie indtil 1720. Aabenraa: Historisk Sam- fund for Senderjylland (Skrifter, udgivne af Historisk Samfund for Sønderjylland Nr. 25), 185-239.

Gregersen, H.V. 1967. 'Fra Kielerfreden til Treårskrigen'. I: Johan Hvidtfeldt og Peter Kr. Iversen (eds.), Åbenrå Bys Historie II 1721-1864. (Skrifter, udgivne af Historisk Samfund for Sonderjylland Nr. 25). Åbenrå: Historisk Samfund for Sønderjylland.

Greve, Klaus 1987. Zentrale Orte im Herzogtum Schleswig 1860. (Studien zur Wirtschafts- und Sozialgeschichte Schleswig-Holsteins 12) Neumünster: Wachholtz.

Grove-Stephensen, F.S. 1985. Skibsfarten $i$ Slesvig 1750 med særlig henblik $p d$ Åbenrå, Sonderborg, Flensborg og Egernforde. Utrykt manuskript i Arkivet ved Dansk Centralbibliotek for Sydslesvig, Flensborg.

Haase, Nicolai 1925. Das Aufkommen des gewerblichen Grossbetriebs in SchleswigHolstein. Kiel (Quellen und Forschun- 
gen zur Geschichte Schleswig-Holsteins XI).

Henningsen, Lars N. 1977. 'Byboere, landboere og brændevin'. Sønderiysk Månedsskrift, 13-22.

Henningsen, Lars N. 1978. Fattigzxsentet $i$ de sønderjyske kobstader 1736-1841. Åbenrå: Historisk Samfund for Sønderjylland (Skrifter, udgivne af Historisk Samfund for Senderjylland $\mathrm{Nr}$. 47).

Henningsen, Lars N. 1984. 'Lebensmittelversorgung und Marktverhältnisse in Flensburg im 18. Jahrhundert'. I: Flensburg 700 Jahre Stadt. - eine Festschrift. Flensburg (Schriften der Gesellschaft für Flensburger Stadtgeschichte, Nr. 36,1) 207-229.

Henningsen, Lars N. 1985. Provinsmatndorer fra 1700-årene. Reder-, kbbmandsog fabrikantfamilien Otte $i$ Ekernforde $i$ okonomi og politik 1700-1770. Flensborg: Studieafdelingen ved Dansk Centralbibliotek for Sydslesvig.

Henningsen, Lars N. 1989. 'Et »flittigt og oeconomisk folk «. Tilvirkning og salg af tekstiler fra Nordøstslesvig i 1700-årene'. Senderjyske Arboger, 127166.

Henningsen, Lars N. 1990a. 'Kobmand Jacob Schwennesen i Aabenraa'. Sonderjysk Månedsskrift, 1990, 35-41.

Henningsen, Lars N. 1990b. 'Penge og ånd. Flensborg-købmanden Hans Feddersens vej til brødremenigheden'. Sønderjuske Årboger, 57-72.

Henningsen, Lars N. 1990c. 'Bødkersvendene i Flensborg'. Senderjysk Månedsskrift, 243-50.

Henningsen, Lars N. 1991. 'Slesvigs og Holstens administration'. I: Erik Alstrup og Poul Erik Olsen (eds.), Dansk kulturhistorisk Opslagsværk. Aarhus: Dansk Historisk Fællesforening.

Henningsen, Lars N. 1992. 'Handelsbyen Haderslev i 1700-årene - set fra købmand Peter Rabens krambod'. Sonderjyske Arboger, 53-72.

Henningsen, Lars N. 1998. 'Die Zusammenführung Schleswigs unter dänischer Herrschaft - Idee oder Realität'. I: Geschichte Schleswigs vom friihen Mittelalter bis 1920. Aabenraa: Institut for Grænseregionsforskning, 61-79.

Hjelholt, Holger 1942. 'Tidsrummet c.
1660-1805'. I: Vilh. la Cour (eds.), Sonderiyllands Historie fremstillet for det danske Folk. III. København: Reitzel 155-484.

Hjelholt, Holger 1943. 'Tonder under Kongestyre 1713-1864'. I: M. Mackeprang (eds.), Tonder gennem Tiderne. (Skrifter, udgivne af Historisk Samfund for Sonderiylland Nr. 3) Tønder.

Hvidtfeldt, Johan 1960. 'Tidsrummet 1667-1807'. I: Holger Hjelholt (eds.) Sonderborg bys historie 1. Sonderborg, 97-210.

Hähnsen, F. 1923. Dic Entwicklung des ländlichen Handwerks in Schleswig-Holstein. Kiel. (Quellen und Forschungen zur Geschichte Schleswig-Holsteins IX)

Ibs, Jürgen H. 2004. Historischer Atlas Schleswig-Holstein vom Mittelalter bis 1867. Neumünster: Wachholtz Verlag. Momsen, Ingwer Ernst 1969. Die Bevöikerung der Stadt Husum von 1769 bis 1860. Versuch einer historischen Sozialtopographie. Kiel: Schriften des Geographischen Instituts der Universität Kiel.

Momsen, Ingwer Ernst 1978. 'Die Berichte über die wirtschaftlichen Verhältnisse in den Städten und Ämtern der Herzogtümer Schleswig- und Holstein ... 1735'. Rundbrief des Arbeitskreises fiir Wirtschafts- und Sozialgeschichte Schleswig-Holsteins 2, 3035.

Momsen, Ingwer Ernst 1996. 'Statistik des schleswig-holsteinischen Schiffsbestandes 1745-1865'. Rundbrief des Arbeitskreises fiur Wirtschafts- und Sozialgeschichte Schleswig-Holsteins, 66, 3751 og 67, 23-47.

Niemann, August 1799. Handbuch der schleswig-holsteinischen Landeskunde. Topographischer Teil. Erster Band. Herzogthum Schlestuig. Schleswig.

Pingel, Fiete 2003. 'Von der Ruhe des Nordens bis zum Staatsbankrott (1713-1813)' I: Geschichte Husums von den Anfüngen bis zur Gegenzuart. (Schriften der Gesellschaft für Husumer Stadtgeschichte 3). Husum.

Schröder, Johannes von 1837. Topographie des Herzogthums Schlestoig. Schleswig. 
Schütt, Hans-Friedrich 1966. 'Flensburg in der Zeit des Gesamtstaates'. I: Flensburg Geschichte einer Grenzstadt. Flensburg: Gesellschaft für Flensburger Stadtgeschichte, 169-235.

Schütt, Hans-Friedrich 1971a. 'Apenrade'. I: Schifffahrt und Häfen von Tondern bis Brunsbüttel, won Hadersleben bis Schleswig, Flensburg: August Westphalen, 171-187.

Schütt, Hans-Friedrich 1971b. 'Flensburg, Segelschiffzeit'. I: Schifffahrt und Häfen von Tondern bis Brunsbiuttel, von Hadersleben bis Schleswig, Flensburg: August Westphalen, 89-114.

Staeglich, Helmut 1989. 'SchleswigHolsteinischer Kanal und Elbblockade'. I: Tönning im Wandel der Zeiten. Husum.

\section{NOTER}

1. Becker-Christensen 1988, 219-250, 424-456, 500, 523.

2. Henningsen $1991,808-812$.

3. Greve 1987. Ibs 2004.

4. Feldbæk 1982, 125. Beiträge 1967, 9 og 13-15.

5. Momsen 1996. For Kongeriget se Anders Monrad Møller: Fra galeoth til galease, 1981 s. 29 og bilag 3.

6. Niemann $1799,562-607$. Hjelholt 1942, 357-358, 447-450.

7. Worsøe 1967, 73, 85, 87, 92, 94.

8. Henningsen 1985.

9. Dyssel 1924-25, 173. Worsøe 1967, 95 (Fabricius 1764)

10. Skatteregistre over formue- og næringsskatten 1744:

Landsarkivet for Sønderiylland, Tønder byarkiv 278 .

Rigsarkivet, Tyske Rentekammer G 97: Sønderborg og Aabenraa,

G 98: Haderslev.

Stadtarchiv Flensburg XII Hs 2077: Flensborg.

Landesarchiv Schleswig-Holstein, Abt 167 AR 1746 Flensburg 93, 94.

11. Henningsen 1990a.

12. Henningsen 1992.

13. Schütt 1966.
Vaagt, Gerd 1966a. 'Kriegsjahre und liberale Strömungen'. I: Flensburg $\mathrm{Ge}$ schichte einer Grenzstadt. Flensburg: Gesellschaft für Flensburger Stadtgeschichte, 235-300.

Vaagt, Gerd 1966b. 'Die Jahre der nationalen Auseinandersetzung'. I:Flensburg Geschichte einer Grenzstadt. Flensburg: Gesellschaft für Flensburger Stadtgeschichte, 301-346.

Worsøe, Hans H. 1967. 'Tiden 17211814'. I: Johan Hvidtfeldt og Peter Kr. Iversen (eds.), Åbenrå Bys Historie II 1721-1864. (Skrifter, udgivne af Historisk Samfund for Sonderjylland $\mathrm{Nr}$. 25). Åbenrå: Historisk Samfund for Sonderjylland.
14. Grove-Stephensen 1985.

14. Henningsen 1989. Henningsen $1990 \mathrm{~b}$.

15. Pingel 2003, 105. Momsen 1969.

16. Henningsen 1990c.

17. Hähnsen 1923.

18. Henningsen 1977.

19. Henningsen 1989.

20. Henningsen 1984.

21. Momsen 1978. Hjelholt 1942, 334, 347.

22. Haase 1925. Henningsen 1985, 171-234.

23. Henningsen 1978, 98-105.

24. Henningsen 1991, 812.

25. Hvidtfeldt 1960, 102-104, 109-127.

26. Henningsen 1998, 64-66.

27. Gregersen 1961, 226-230. Henningsen 1985, 25-39.

28. Gregersen 1961, 226-230. Worsøe 1967, 91-97. Henningsen 1985, 44. Hvidtfeldt 1960, 135-138, 143, 147$148,162-163,169$.

29. Andersen $2000,98-99$.

30. Andersen 2000, 99, 221.

31. Staeglich 1989, 48-57. Hjelholt 1942, 457.

32. Fangel 1975, 15-146.

33. Worsøe $1967,87-97$. Andersen 2000, 99 og 221. 
34. Hvidtfeldt 1960, 169.

Andersen 2000, 221.

35. Niemann $1799,681-720$.

36. Niemann 1799, 562-607.

Andersen 2000, 99, 221.

37. Fangel 1975.
38. Schröder 1837 II, 228-242.

39. Gregersen 1967, 139-144.

Schütt 1971a, 171-188.

40. Vaagt 1966a, 242-247, 285-292. 1966b, 334-341.

Schütt 1971b, 105-107. 